\title{
Thermal burn during open heart surgery
}

\author{
Oparzenia cieplne podczas operacji na otwartym sercu
}

\author{
Mahnoosh Foroughi, Seyed Ahmad Hassantash, Hossein Rahimian, Aazam Noori, Kamran Ghods, \\ Mehran Shahzamani
}

Research and Development Center, Modarres Hospital Saadat-Abad, Tehran, Iran

Kardiochirurgia i Torakochirurgia Polska 2012; 3: 295-298

\begin{abstract}
Background: Electrosurgery helps surgeons to perform procedures faster and with less bleeding.

Aim of the study: This paper was designed to illustrate some aspects of electrical burns, their potential causes in our operating room and the method which guided us to the technical solutions of the problem.

Material and methods: This case-control study included 129 patients who underwent cardiac operations at a tertiary university medical center. Forty-one patients experienced burn during the operation during this period. The demographic and perioperative characteristics of this group (as case group) were compared to the remainder (88 patients) who had operations on the same days, but had no burns (as control group). Causative factors and preventive measures were reviewed.

Results: It was observed that a greater number of patients in the burn group had diabetes and hypertension, were operated on in an emergency setting $(P=0.001)$, and had a longer aortic clamp time. After the assessment of the monopolar electrosurgery equipment and restoring the electrical conditions of the operating rooms, it was determined that the shields covering the operating table were not completely insulated from current. Conclusions: Burning was the result of incomplete insulation of the patients from the operating table. Identifying the pitfalls in dealing with electrosurgery and simple precautions help to reduce such preventable complications.

Key words: burn, electric, electrosurgery, operating room.
\end{abstract}

\section{Introduction}

The concept of using heat to decrease bleeding goes back to thousands of years ago, since cavemen found that a burning stick could stop bleeding and seal off a wound [1]. Bovie and Cushing established electrosurgery using

\section{Streszczenie}

Wstęp: Elektrokoagulacja pomaga chirurgowi w przeprowadzeniu zabiegu w krótszym czasie i z mniejszym krwawieniem. Cel pracy: W pracy przedstawiono niektóre aspekty oparzeń wynikających z zastosowania urządzeń elektrycznych w warunkach sali operacyjnej oraz propozycje sposobów mających pomóc w unikaniu tego rodzaju powikłań.

Materiał i metody: Praca objęła 129 chorych, u których wykonano operację kardiochirurgiczną w ośrodku uniwersyteckim o trzecim stopniu referencyjności. U 41 chorych stwierdzono oparzenia w trakcie zabiegu (grupa badana). Analizowaną grupę porównano pod względem czynników demograficznych i śródoperacyjnych z grupą kontrolną 88 chorych, u których przeprowadzono zabieg w tym samych dniach, ale bez oparzeń. Wyniki: W grupie badanej w porównaniu z kontrolną częściej stwierdzano obecność cukrzycy i nadciśnienia tętniczego oraz konieczność przeprowadzenia operacji w trybie nagłym $(p=0,001)$ z dłuższym czasem zaklemowania aorty. Po dokładnej ocenie monopolarnego sprzętu do elektrokoagulacji i przywróceniu prawidłowych warunków funkcjonowania sal operacyjnych ustalono, że osłony pokrywające stół operacyjny nie gwarantowały pełnej izolacji pacjenta przed prądem.

Wnioski: Oparzenia były konsekwencją niepełnej izolacji chorego od stołu operacyjnego. Identyfikacja prostych błędów podczas użytkowania sprzętu do elektrokoagulacji pozwala zmniejszyć częstość występowania tego rodzaju powikłań.

Słowa kluczowe: oparzenie, elektryczny, elektrokoagulacja, sala operacyjna.

high-frequency alternating current in neurosurgical procedures in the 1920s [1]. Electrosurgery helps surgeons to perform procedures faster and with less bleeding, and also allows some previously inoperable patients to be operated on $[2-3]$.

Address for correspondence: Mahnoosh Foroughi, Research and Development Center, Modarres Hospital, Saadat-Abad, Tehran, Iran. P.O. Box: 13185-1678, Tehran, Iran, Tel. +9821 66439463, Fax +9821 66423304, Email: swt_f@yahoo.com 
Currently electrosurgery units are present in almost all operating rooms. However, it is probably the unit least identified by the operating room personnel and physicians [4-5].

The number of accidental injuries voluntarily reported from operating rooms is less tangible in the real world; so awareness of this experience may decrease its rate [6-8]. The purpose of this paper was to state patterns of thermal burn due to using electrosurgery in our operating rooms, potential causes and ways that directed us to solve the problem.

\section{Material and methods}

Data were collected from the database of the cardiac surgery department at Modarres Hospital, a tertiary affiliated medical university center. Between March 2007 and March 2009, more than 2100 cardiac operations were performed. It was observed that a few patients suffered skin burns in the operating room during this interval. The study was approved by the ethics committee of the hospitals and was conducted in conformity with the Helsinki Declaration.

\section{Patients}

Forty-one of the patients (1.95\%) who underwent cardiac operations had burns. Demographic and perioperative characteristics of these patients (as case group) in four active operating rooms were compared to the remainder (88 patients, as control group) who had been operated on the same days, without burning (with the same anesthetic management, staff and resident of cardiac surgery, and identical electrosurgery machines in the same operating rooms). Burning happened only in patients undergoing surgery with cardiopulmonary bypass (CPB). Standard and identical operative and anesthetic techniques were used in all patients. Moderate systemic hypothermia $\left(28-32^{\circ} \mathrm{C}\right)$ was used during CPB.

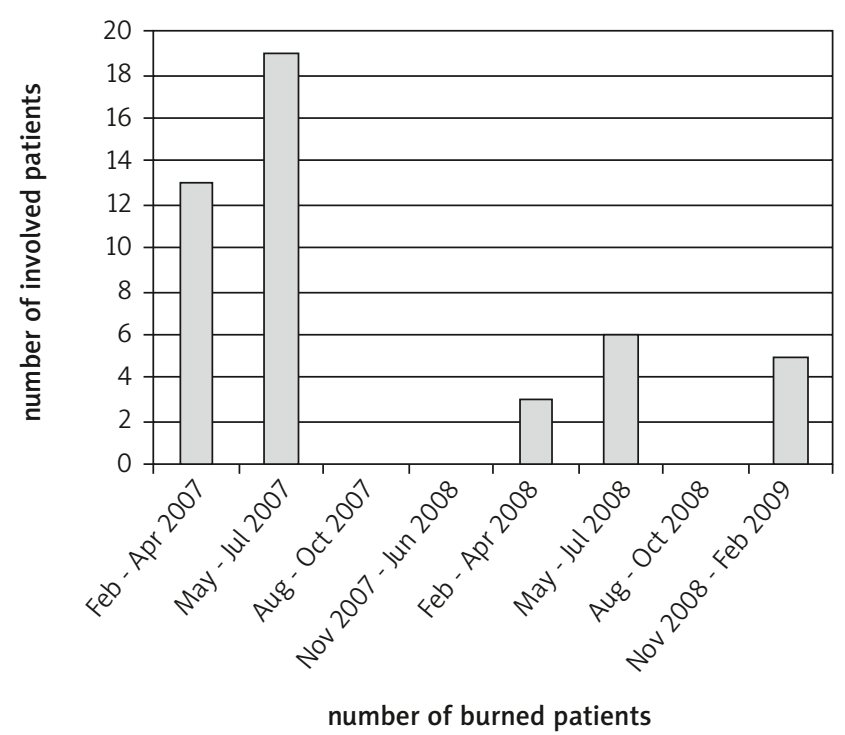

Fig. 1. Burning episodes during 2007-2009
Because episodes of burning occurred more predominantly in specific periods of time (Fig. 1), basic examination was undertaken to find the causative factor.

\section{Statistical analysis}

Results are presented as mean \pm standard deviation. We used $\chi^{2}$ and Mann-Whitney test to compare the occurrence between the two groups. Variables found to be predictors of burn in the univariate analysis were then entered into a multivariate model using logistic regression to determine the independent predictors of burn. $P$ value of $<0.05$ was considered statistically significant.

\section{Results}

\section{Patient characteristics}

Forty-one patients had burn injuries after open heart surgery. There were no differences between the groups in terms of surgeons, residents and operating rooms. The skin injuries were all located in the sacral and gluteal regions (at the place of the return electrode placement), except for 2 patients whose wounds were limited to the occipital region. Both gluteal and foot involvement were seen in three cases. The average lesion size was $15 \mathrm{~cm}^{2}$. Thirty-one patients had superficial burns (local tenderness, erythematous change, bulla formation). The rest (10 patients) presented full-thickness burns; $50 \%$ of them required surgery, including debridement, or musculocutaneous gluteus maximus flaps, and the remainder were treated conservatively. There was mortality due to this complication too. Death occurred in a patient who had a burn at the return electrode site. Ten days after discharge, he returned to the hospital in septic shock due to necrotizing fasciitis. Multiple extensive debridements did not improve the patient's outcome.

The mean ages were $59.4 \pm 14.6$ in the burn group and 56.6 \pm 12.7 in the control group $(P=0.23)$. Ejection fraction of the left ventricle as a marker of cardiac output was comparable in the two groups ( $47 \pm 10.3 \%$ in the burn group and $48 \pm 9.4 \%$ in the control group, $P=0.6$ ). More patients in the burn group were operated on in an emergency setting $(P=0.001)$ and they had a longer clamp time and intubation time with lower body surface area (BSA): $1.6 \pm 0.2 \mathrm{~m}^{2} \mathrm{vs} .1 .7 \pm 0.2 \mathrm{~m}^{2}, P=0.02$ ).

We performed a multivariate analysis using logistic regression to identify the major variables in burning. We found that hypertension, diabetes, prolonged clamp time and intubation predispose patients' skin to more ischemia, while better peripheral circulation with less BSA and improved oxygenation by blood transfusion had a protective effect in low perfusion states.

\section{The following steps were taken to eliminate the problem}

Three wires are distributed to all electrosurgery devices in the operating room: a "hot" lead, a neutral or "ground" lead, and a ground wire. The neutral lead is connected to the ground at the point that the electrical wiring enters the building. These two wires connect to the device to power 
it. The "ground wire" is attached to the ground at this point too (it is also connected to copper plates by a cable which is buried in a well acting as the "ground" in the connection; copper plates are surrounded by salt). The ground lead is used to return any current leaking from it back to the earth.

At first, it was verified that due to rainfall, the salt between the copper plates in the well had washed off, so it had become inefficient. Help was sought from the electric company; the cover plates and the cable were replaced. Due to additional burn cases, and uncertainty about the well, a new well was constructed. All electrosurgery equipment was also checked by its company. None of these remedies solved the problem.

At the second phase, the operating room was suspended for three months. With further assessment, it became apparent that in some outlets, the null connections had short-circuited, and this difficulty was resolved by separating them. The null connection for the floor carpet, the wiring of the operating room, and its fuse box were all changed by the engineering department. Although the frequency of burning had clearly decreased, the dilemma still remained.

Finally, an unexpected observation resolved the problem. The main fault was the quality of shields covering the operating table which were supposed to be electrical barriers, but in fact had two surfaces with different electrical properties (conductor and insulator). By pure chance, we found that if the insulator surface of the covering came in touch with the patient's body, the patient would not be burned; on the other hand, if the conductor surface of the covering was in contact with the patient and it had tiny holes, he or she would be injured. After this simple finding and changing of the bed coverings, there have been no new burn reports.

\section{Discussion}

"I shall protect them from all harm". From the Hippocratic Oath. This means during any intervention, no additional injury must influence the patient.

The main difference between cardiac surgery and other types of surgery is the presence of CPB. At first, blood dilution by adding the prime volume of CPB could temporarily create a state of insufficient oxygen content [9]. On the other hand, oxygen availability is reduced during hypothermia because of the shift to the right of the oxyhemoglobin curve [9]. Regardless of the negative effect of allograft transfusion on surgical outcomes in literature, multivariate analysis showed a protective impact of transfusion against burn [9]. This may be explained by providing better oxygen content in the lower perfusion state during CPB and in the setting of peripheral ischemia.

Secondly, CPB prevents normal reflexes and chemoreceptor control of the circulation. The reduction in oxygen consumption from surface cooling could be from the shutting down of the microcirculation of skin and visceral portions of the body. Clinical information strongly suggests that blood flow to the skin is severely reduced during nonpulsatile CPB in humans [10]. The combination of the patient's immobility during lengthy procedures and prolonged intubation predisposed patients to develop full thickness burns in areas that were already at lower perfusion pressure during aortic clamping. The development of increased local pressure at contact points between the patient and the table (skin over the forehead, iliac crests, and bony prominences on the arms and legs) causes the skin to be at risk of damage. So it is reasonable that places of poorly perfused skin during CPB are prone to electrical burn. Multivariate analysis showed that hypertension and diabetes were causative factors in predisposing skin to burn. They cause alterations of structure and function in the microcirculation [11]. Diabetic microangiopathy is a very frequent complication of diabetes mellitus and capillary density is reduced in hypertensive patients [12]. To address these concerns, the explanation is clear and simple: low perfusion pressure, defect in microcirculation, local pressure and electrical burn.

Burning events appeared more often in emergency operations. The cause could possibly be described as emergency conditions providing opportunities for errors and lack of complete insulation of the patient from the operating table.

\section{Limitations}

The strength of this study is reporting the errors rather than blaming individuals. Knowledge of the biophysics of electrosurgery, the mechanisms of electrosurgery complications, and prevention of patient injuries allows surgical team members to provide better quality outcomes for patients. However, this study has several limitations. Our study was observational, not interventional; it was a single institution and retrospective study. It was conducted on patients undergoing cardiac surgery at an urban, academic medical center and thus our results may be generalized to other hospitals.

\section{Summary}

Preventable complications are always a concern to the surgeon. Thermal burns during electrosurgery are not uncommon and constitute the most common electrical hazard in the operating room. It seems that the simplest way to avoid burns is to educate those who use electrosurgery.

\section{Acknowledgements}

The authors gratefully acknowledge the statistical support by Yadollah Mehrabi and also appreciate Khosro Sohrabi for review of the manuscript and Naser Valaee for helpful suggestions. And also the author would like to thank Farzan Institute for Research and Technology for technical assistance.

No conflict of interest; no funding source.

\section{References}

1. Revercomb CH, Stewart CE, Bux RC. Artifact from an electrosurgical ground pad. Am J Forensic Med Pathol 1997; 18: 293-294.

2. Ziprin P, Darzi AW. Monopolar electrosurgery. Risks and their reduction. Prob Gen Surg 2002; 19: 18-23. 
3. Hutchisson B, Baird MG, Wagner S. Electrosurgical safety. AORN J 1998; 68: 829-883

4. Van Way CW 3rd. Electrosurgery 101. Curr Surg 2000; 57: 172-177.

5. Huschak G, Steen M, Kaisers UX. Principles and risks of electrosurgery. Anasthesiol Intensivmed Notfallmed Schmerzther 2009; 44: 10-13.

6. Jones CM, Pierre KB, Nicoud IB, Stain SC, Melvin WV 3rd. Electrosurgery. Curr Surg 2006; 63: 458-463.

7. Wang K, Advincula AP. "Current thoughts" in electrosurgery. Int J Gynaecol Obstet 2007; 97: 245-250

8. Vancaillie TG. Active electrode monitoring. How to prevent unintentional thermal injury associated with monopolar electrosurgery at laparoscopy. Surg Endosc 1998; 12: 1009-1012.

9. Ranucci M, Pazzaglia A, Bianchini C, Bozzetti G, Isgrò G. Body size, gender, and transfusions as determinants of outcome after coronary operations. Ann Thorac Surg 2008; 85: 481-486.

10. Stamler A, Wang SY, Aguirre DE, Johnson RG, Sellke FW. Cardiopulmonary bypass alters vasomotor regulation of the skeletal muscle microcirculation. Ann Thorac Surg 1997; 64: 460-465.

11. James MA, Tullett J, Hemsley AG, Shore AC. Effects of aging and hypertension on the microcirculation. Hypertension 2006; 47: 968-974.

12. Prázný M, Skrha J. Microcirculation in the skin of the upper extremities in type 1 diabetics using the laser doppler method. Cas Lek Cesk 2000; 139: 309-312. 